\title{
Education for Loneliness as a Consequence of Moral Decision-Making: An Issue of Moral Virtues
}

\author{
Jarosław Horowski ${ }^{1}$ (i) \\ Published online: 13 July 2020 \\ (c) The Author(s) 2020
}

\begin{abstract}
The direct reference point for these analyses is the process of making moral decisions, but a particular point of interest is the difficulty associated with making decisions when acting subjects are aware that their choice of moral good can lead to the breakdown of relationships with those close to them (family members or friends) or to their exclusion from the group(s) that have been most important to them so far in their lives, consequently causing them to experience loneliness. This difficulty is a challenge for education, which in supporting the moral development of a maturing person should prepare her/him for choosing moral good even if this requires personal sacrifices. In these analyses, assuming that knowledge of moral good is not sufficient for morally good actions, I refer mainly to the virtues of character that facilitate making morally good decisions and I seek the answer to the question: what character traits (moral virtues) should be shaped in maturing persons, so that as adults they can resist moral evil, even when this will clearly lead to the experience of loneliness? I propose these character traits as expressing moral virtues-especially the cardinal virtues of prudence, justice, temperance and fortitude (neo-Thomistic approach). In this way, I join in the discussion relating to the teleology of education. I do not touch on the methodology of education, however. The argument is presented in two parts. In the first, I introduce the problem of decision-making implying consent to loneliness. In the second, I reflect on the characteristics of a person who is capable of making such a decision.
\end{abstract}

Keywords Loneliness · Difficult moral decision · Virtues · Fortitude · Longanimity · Teleology of education

\section{Introduction}

Making moral decisions can be difficult for people, especially when the choice of moral good is accompanied by severe consequences, for example, when the person making the decision is aware that obedience to her/his good conscience will lead to the loss of goods or will prevent the achievement of goods that were previously a subject of endeavour. Equally

Jarosław Horowski

jarohor@umk.pl

1 Department of Theory of Education, Faculty of Philosophy and Social Sciences, Nicolaus Copernicus University in Toruń, Toruń, Poland 
difficult, if not more difficult, is the making of a morally good decision in opposition to the aspirations and endeavours of those close to a person, which may result in loss of contact with these people (breaking a relationship with a parent, child or friend, for example) or exclusion from a group of people who have been a basic part of the person's life experience to date. Awareness of such a possibility can lead not only to hesitation, but also to the abandonment of a morally good solution and the choice of a worse one so that the relationship with a significant person or group is not broken. However, the choice to abandon a morally good solution and/or the choice of a worse one comes at a price. Not only are other people whose good has been violated the victims of such an action, but so too are the perpetrators themselves. This leads them to an awareness of the evil they have caused and of the consequences suffered by other people, and sometimes to remorse they cannot cope with for years. When Robin S. Dillon begins his analysis of self-forgiveness, he quotes the story of a woman who could not cope with an episode in her teens and felt something similar to self-loathing. She had been afraid of rejection by her peers at school, who mocked her disabled friend, so she didn't resist them. She also made fun of her friend's appearance when her friend was not there (Dillon 2001, p. 53). The problem outlined above is a challenge for education. If education is to support the moral development of young people, it should prepare them for making difficult decisions that require sacrifice, including decisions that are in opposition to the aspirations of those close to them and which thereby result in the experience of loneliness.

In this article, I address the issue of education in the making of such decisions and specifically focus on positive character traits, i.e. moral virtues, which should be shaped in maturing people, so that despite the possible breakdown of relationships or exclusion from significant groups, they are still capable of choosing moral good. I refer to the category of virtues for two reasons. I do so firstly because I assume that in specific cases making moral decisions may differ from the identification of theoretical solutions to moral problems. Consequently, education limited to the development of theoretical competences can make it easy to find the best solutions in a given situation, but having these competencies doesn't necessarily lead a person to face the challenge of actually implementing those solutions (Horowski 2014). People who are well able to indicate what should be done from a moral point of view may have problems with implementing specific solutions because of fear of the consequences. Meeting the abovementioned challenge is easier when the individuals have developed certain virtues, such as the virtue of courage. Secondly, I refer to the category of virtues because, in recent years, there has been increasing interest in the issue of virtues as a result of the achievements of empirical sciences, which have become the basis for posing questions about the process of the formation of permanent character traits in developing persons. In this context, virtue theory provides an opportunity for discussion between ethics and the empirical sciences. Consequently, the category of virtue is used to define aims of education (Carr 1991; Curren 2015; Snow 2016; Szutta 2017; Żywczok 2019).

The abovementioned discussions on character education are conducted primarily in reference to the Aristotelian theory of virtues, which in Anglo-Saxon philosophy has experienced a renaissance through reflection by Elizabeth Anscombe (1958) and works by Alasdair MacIntyre, especially the book After Virtue. A Study in Moral Theory (2007). Currently, there is extensive literature in the field (Arthur et al. 2016; Carr 1996, 2017; Eaude 2016; Kristjánsson 2015; Kaźmierczak 2019). In my analyses, I use neo-Thomistic philosophy, which has been developed intensively since the end of the 19th century in Catholic circles (Mausbach 1920; Pieper 1966; Gilson 2002; Woroniecki 1922; Horowski 2015, pp. 78-82; Keenan 2016) and for which the issue of harmony between reason and 
sensual desires was very important. Referring to neo-Thomistic philosophy, I pose a question: what character traits (moral virtues) should be shaped in maturing persons, so that as adults they can resist moral evil, even when this will clearly lead to the breakdown of relationships or rejection by a group of people important to the moral decision-maker, and therefore to loneliness? Answering this question, I join in the discussion relating to the teleology of education. I do not address the methodology of education, which requires a separate study.

The reflections in the article are divided into two parts. In the first part, I analyse the moral recognition of evil in the situation where individuals considering moral dilemmas are aware of consequences that are difficult personally, that is, the breakdown of relationships or exclusion from a significant group. The second part contains a reflection on the moral virtues people must have to make such decisions in light of their awareness of these consequences. Using Thomistic and Neo-Thomistic philosophy as a frame of reference, cardinal virtues will become the basic subject of analyses. To sum up the article, I draw conclusions in relation to education.

\section{Moral Decision-Making and Awareness of the Breakdown of Important Relationships}

The direct reference point for these analyses is the process of making moral decisions, but a particular point of interest is the context in which these decisions are made, that is, the circumstances in which moral decisions are made and the collateral consequences of those decisions.

When making a decision, a person must first determine what they should do in a given situation from a moral point of view, that is, s/he must compare the object of the act with the moral norms s/he recognizes as relating to a given action (Maritain 1990; Richardson 2018). This reasoning seems easy when one does not take into consideration two circumstances. The first of these circumstances is when the decision relates to one subject and one object, while the additional circumstances and consequences are ignored. The need to take into consideration all direct and indirect effects of an act leads to numerous moral dilemmas, however. The second of these circumstances is when the analysis does not lead directly to an act, but is purely theoretical speculation. The need to actually make a decision and bear the consequences of that decision can cause intense emotions-for example, fear of the pain and suffering that might be caused by a specific decision-which can then lead to the abandonment of the act (Maritain 1967; Spaemann 2006). These two circumstances are related to each other, but the first plays a key role.

Dilemmas that individuals must actually face are difficult to solve, because the effects of given acts are not experienced just by the person who is the direct object of these acts. Indirectly, specific acts lead to consequences in the lives of people close to the subject/moral decision-maker, who can be helped or harmed by the acts. Furthermore, these acts can change not only the life of the subject her-/himself, but also the lives of people associated with her/him. Sometimes, finding solutions that are beneficial for all those who will experience the consequences of an act is extremely difficult (Spaemann 2006). The difficulty is compounded by the fact that people close to the subject have goals they pursue that sometimes conflict with the good of others. The subjects refer not only to the good of the persons directly experiencing the effects of their actions, but also to the good for which the people close to her/him strive. Sometimes, choosing moral 
good requires that a subject oppose the aspirations of her/his family members or friends. An example of such a situation is the awarding of a prize by the head of an institution that both the subject's friend and a stranger apply for. One person winning means the other person losing. The victory of a stranger may mean not only the loss of a friend, but it can also affect the future career of this friend or the extent to which they achieve their personal goals. Sometimes, loved ones exert pressure on a person to support them in achieving morally negative goals. Therefore, they expect the person to harm strangers because of friendship or family ties. The closeness and strength of relationships connecting these people can be a source of strong pressure on the subject. Another example of a decision seen as contrary to the interests of loved ones is the decision to inform the police about a crime. In this situation, the person reports the crime acts in favour of the victim, and at the same time this action is perceived by family members or friends as being against them. The decision to report a crime committed by a brother, sister or child that the perpetrator of the crime tries to hide and that is punishable by imprisonment can be an extremely difficult one to make.

One of the side effects of opposition to evil and the decision to choose moral good may be the breakdown of relationships with close persons, family members or friends, or exclusion from groups of people who have been important in the life of the acting subject so far. Some relationships are difficult to replace and others cannot be replaced. While it is possible to build a new friendship and even remarry, a mother, father or child cannot be replaced. Breaking a relationship with such close persons leads to the experience of emptiness. Sometimes the whole family turns away from one of its members who has advocated for the good of strangers. Breaking relationships with loved ones leads to the experience of loneliness, even if the individual is surrounded by other people. This effect is not wanted directly by the subject, but can be indirectly triggered by that person, and is an important factor in the process of moral decision-making. To demonstrate its meaning, it is necessary to look first at loneliness itself.

Contemporary philosophical, psychological and theological literature indicates that solitude is something that is natural and has value for human development and functioning. In philosophy, solitude is perceived as complementary to communitiveness and it is emphasized that each person incorporate in her/his life some periods of being in community and some episodes of solitude (Arendt 1978; Domeracki 2020). In psychology, solitude is considered a factor in maintaining mental balance and harmonizing personality (Mijuskovic 2015; Cleveland 2020). In theology, solitude is seen as a space for spiritual and religious development (Merton 1998; McGregor 2016; Budzanowska-Weglenda and Jewdokimow 2019). While solitude and loneliness are not identical, and with loneliness usually understood as something negative, it is worth noting that even being left by loved ones and experiencing loneliness can become an opportunity to look at reality from a different perspective. Job's history is an example of this. Job was a religious man in the sense that he fulfilled the rules of his religion; yet he never talked to God. He experienced suffering and felt misunderstood by his wife and friends. As a consequence of loneliness, he began to speak directly to God and met God in a completely different dimension (Martini 1992). His last statement contains the words: 'In the past I knew only what others had told me, but now I have seen you with my own eyes' (Job 42: 5). One can say that the Book of Job shows religious development in Job from a state of traditional, external religiosity to one of personal faith-a development which took place in the context of the experience of loneliness. The value of solitude (and even loneliness) discovered by various disciplines mean that in pedagogy too there is a rich literature on the positive aspects of solitude, arguing that it helps to reveal the unique 'I', build an identity, locate a person's own answers to 
the most important existential questions, and develop spiritually and intellectually (Stern 2014; Stern and Wałejko 2020; Rembierz 2013; Wałejko 2007, 2016; Kostyło 2015).

Although the value of loneliness is appreciated in scientific reflection, it is difficult to deny that loneliness is feared in contemporary culture. As Piotr Domeracki points out, many people try compulsively to escape a sense of loneliness (Domeracki 2018, pp. 28-48; cf. Tillich 1980; Stern 2014, p. 182). There are certainly many reasons-with both an objective and a subjective character-for this attitude. Certainly, the breakdown of a relationship with family members or close friends causes a sense of lacking and emptiness (Stern 2014) in the life of rejected or excluded people. Jules Henry combines the topic of loneliness with the issue of vulnerability. In his analysis, the desire to maintain relationships is a consequence of the need to be protected by other people. Loneliness is interpreted as the loss of a sense of security in a given situation. Henry even states that fear of losing security creates a sense of loneliness: 'there is practically a direct relation between the intensity of fear and the belief that we need people to protect us, it seems to me that the more we fear, the lonelier we feel' (Henry 1980, p. 102). Domeracki identifies completely different, culture-related conditions for avoiding loneliness. He presents the development of a mental stereotype, according to which staying in the community (pólis) is synonymous with socialization, while staying out of the community is a consequence of a lack of sociomoral refinement (Domeracki 2018, pp. 176-186). Exclusion from the group-from the family, for example - can therefore lead to the perception that a person is socially maladjusted, and individuals want to avoid this perception.

Moreover, because loneliness is associated with suffering and is a difficult experience to bear, difficulties with accepting it intensify in contemporary culture, where loneliness is perceived negatively, leading individuals to try to avoid it. Many people are afraid of rejection by their family or friends and of the experience of loneliness. This is why they decide to compromise, do not give their opinion, and do not oppose those close to them or a group that is important to them. In this context, the desire to connect with other humans becomes a kind of enslavement.

Choosing moral evil to avoid loneliness is not a solution to the problem. This choice has negative consequences, which are experienced not only by injured strangers, but also by the subjects themselves and their relatives or friends with whom they want to maintain relationships. It is particularly important in this case to acknowledge the evil that a person can inflict on her-/himself and the evil that her/his actions can bring to her/his relatives or friends.

As Wojtyła (1994) argues in his study of deeds, the first persons experiencing the effects of given deeds are the subjects themselves, who either become more human-that is, persons who, using their minds, direct their actions-or become persons who do not control their own actions, who are scared, or who succumb to sensual feelings (desires for pleasure). In other words, a given action may develop a person's ability to master desires and fears or it may contribute to the inability to control sensual feelings. Furthermore, if, under the influence of fear of loneliness, a person chooses actions that s/he perceives negatively, then her/his choices mean s/he becomes a person s/he does not want to be.

The effects of given acts carried out by individuals are also experienced by relatives and friends of those individuals, for whom they choose morally negative solutions. If family or friends choose goals such that their accomplishments hurt other people, that is, their actions violate the rights of other people and are connected with treating other people instrumentally, they also contribute to their own negative personal and moral development. Instead of acting sensibly and with respect for the dignity and goodness of another human being, they succumb to sensual desires and seek pleasure or try to avoid suffering, even 
though they are capable of recognizing the moral value of their deeds. In turn, lack of opposition and even cooperation in the pursuit of evil, are, in a sense, consent to the making of morally wrong decisions, moral approval of such actions and, as a consequence, support for the negative moral development of family members or friends.

Therefore, I assume that one of the motives for opposing the pursuit of good that opposes personal and moral development is care for family members and friends who may not be aware of what evil they are inflicting on themselves by their actions. The word 'concern' perfectly expresses this attitude of moral decision-makers. It is used by Margaret Archer (2000) to indicate the conditions of human action. This word indicates that individuals act not so much for their own good as for the benefit of the people they love.

To sum up these considerations, it can be said that the purpose of education is to prepare maturing people to make morally good decisions, including decisions to object to the aspirations of loved ones, even if this results in the risk of a breakdown in relationships with these people. It is not only the preparation for being faithful to the rules or for respecting the dignity of a stranger, but most of all for choosing solutions that are good for both the subject and the people close to her/him—that is, family members and friends.

\section{Moral Virtues that Condition the Morally Good Decision and the Acceptance of Loneliness}

As pointed out in the introduction, the object of my interest is not the morally good decision to oppose a close person's aspirations and endeavours itself, but the character traits that make such a decision easier. The above reflection on the circumstances of making moral decisions allows us to identify several traits that enable an individual to make morally good decisions and consequently to take the risk of breaking relationships or experiencing rejection by groups that are important to her/him, and therefore to experience loneliness. Subjects should recognize the situation well and be able to determine what is good and bad in it. They must also overcome fear of loneliness. Because I use in my analyses the philosophy of Thomas Aquinas, I refer mainly to the cardinal virtues. In addition, I will draw attention to the virtues of hope and longanimity.

Moral efficiency is considered a virtue if it facilitates acting in accordance with reason. As Aquinas claims: 'Wherefore it belongs to human virtue to make man good, to make his work accord with reason' (STh II-II, q. 123, a. 1). He distinguishes four basic virtuesnamed cardinal virtues. They are prudence, justice, fortitude and temperance. These virtues can be divided into two groups. The first group contains prudence and justice, which enable us to determine what someone deserves, and so indicates whether taking the action and supporting close persons is just, that is, morally good, or-on the contrary-the individual should adopt an attitude of opposition. The second group includes the virtues referring to emotions, because these virtues help a person directly to cope with rejection and loneliness. Even though I combine the acceptance of loneliness with the virtue of fortitude in the second group, I will start my analyses with the virtues from the first group.

As Joseph Pieper says: 'Prudence and justice precede fortitude. And that means, categorically: without prudence, without justice there is no fortitude; only he who is just and prudent can also be brave; to be really brave is quite impossible without at the same time being prudent and just also' (Pieper 1966, p. 123). Why are prudence and justice necessary? Because fortitude is just a means to achieve good. Before a person decides to 
act bravely, they must identify a good that is just and they must be just; they must desire that justice be achieved.

There is no doubt that the act of bravery must be preceded by a desire to give to everyone what should be given to them (the virtue of justice). If individuals or members of a group-comprising the people who are close to the subject of our analyses-want something that they do not deserve but which they decide to take away from another person who has the right to it, then supporting them in the accomplishment of this goal is an act of injustice against the person who will be hurt. Brave persons are therefore also just ones, because their bravery is a consequence of the desire for everyone to receive what they deserve.

A similar relation exists between prudence and fortitude. An act of bravery first requires us to identify what a person deserves, what a given person has the right to possess, and what that person does not have the right to possess. The subject must be able to distinguish between what is good and what is wrong in a given situation. It is then necessary to find a solution that respects the rights of all persons and ensures that justice is served. For individuals to mature through the development of prudence, they must acquire the ability to analyse specific situations and determine who should receive what in the circumstances. Brave persons must be able to analyse the situation and choose the best practical solution leading to the achievement of good. To sum up, it is necessary to develop in maturing persons the ability to apprehend reality, to recognize truth and good, and to analyse a given situation in such a way as to identify the best solution, which in turn makes it possible for them to achieve good.

Referring to the concept of Thomas Aquinas, it should be noted that apprehension of the situation and identifying the best solution in given circumstances do not constitute sufficient motivation to act. According to him, there are two forces of the soul: knowing and loving. While in theoretical reasoning we attempt to capture reality and indicate what actions are the most rational, in practical reasoning we seek an intellectual solution to achieve the good that is desired by the will (Bauerschmidt 2015, pp. 231-236). One solution will be chosen by someone who wants to achieve pleasure, another by someone who cares for their family, and yet another by someone who forever strives towards the Absolute as defined through the interpretation of a particular religion (Spaemann 2006). Intellect and will cooperate with each other in the decision-making process (Maritain 1990). For this reason, Jacques Maritain describes intellectualism (which overestimates the importance of the intellect) and voluntarism (which similarly elevates the will) as misconceived traps into which the theory of education falls (Maritain 1943, pp. 18-22; Rajský 2018).

In this context, we should ask: what could lead a specific person to oppose activities of individuals or groups close to her/him? What could lead a particular person not to support her/his relatives in actions that hurt people with whom s/he does not have a relationship? In my opinion, the answers to these questions have already been given. In the first part, I pointed out that every action has direct and indirect consequences. Direct effects are those experienced by the object of the action-a person supported or abused by a given person. Indirect effects are those experienced by the subject. A morally wrong act destroys not only the victim of the act, but also the perpetrator (subject). The perpetrator succumbs to sensual desire, striving for her/his own satisfaction and neglecting the good of others; in other words, through her/his own choice of actions, s/he decides who s/he becomes as a human being. If someone is opposed to the actions of a person close to her/him—risking a situation in which that person will have nothing more to do with her/him (thus exposing her-/ himself to loneliness) - then in my opinion the motive of her/his actions is the good of that 
person. Through her/his actions, s/he is trying to convince the person close to her/him not to become what $\mathrm{s} / \mathrm{he}$ is becoming through her/his own choices.

To sum up this part of article, it should be stated that in the situation analysed here, prudence and justice mean making a decision of opposition for the sake of the good of a loved person or members of a group important to the subject, while anticipating likely rejection by them. Therefore, prudence also includes the ability to recognize the good of this person or these persons - that is, how these people destroy themselves and their lives by pursuing a morally wrong goal, and how they can be made aware of the evil of a particular action. A sound individual must, therefore, perceive her-/himself as a person responsible for the good of others and seek ways to support the personal and moral development of those others.

It is worth noting that prudence is understood in various ways. In everyday discourse, it is associated with an ability to avoid problems. Pieper points out, however, that prudence is not about getting away from problems, but is rather the ability to identify ways of acting that will solve problems, even if the individual has to sacrifice some personal good (Pieper 1966, p. 123).

The second group of relevant virtues includes fortitude, temperance and longanimity, which refer to our feelings. Regulation of emotions is one of the most difficult challenges we must face in the process of our own development. A sound individual may know what to do in a given situation, and may want to accept a difficult challenge, but unregulated feelings may interfere with her/his plans. Neo-Thomistic notions in pedagogy distinguish between the suppression of feelings and the education of feelings, and emphasize the need to refine these through the virtues of fortitude and temperance. Education cannot be understood as the application of techniques of emotional manipulation, but rather as the influence of mental powers: reason and will. Feelings must be convinced in some way to support reason and will in rational actions. This process is called functional (not ontological) sublimation (evocation) of feelings (Horowski 2009, p. 71).

In my opinion, readiness to oppose the aspirations of a person close to us and to accept loneliness as a consequence of this opposition is conditioned by fortitude, the perfection of the irascible power of the soul. According to Aquinas, the task of fortitude is 'removing the obstacles to the establishment of this rectitude [indicated by reason] in human affairs' (STh II-II, q. 123, a. 1). He explains: 'it belongs to the virtue of fortitude to remove any obstacle that withdraws the will from following the reason. Now to be withdrawn from something difficult belongs to the notion of fear, which denotes withdrawal from an evil that entails difficulty [...]. Hence fortitude is chiefly about fear of difficult things, which can withdraw the will from following the reason' (STh II-II, q. 123, a. 3; cf. Gilson 2002, pp. 325-345). Fear of breaking the relationship or rejection and loneliness is an obstacle to rational action, so overcoming this fear is the task of the virtue of fortitude.

Overcoming obstacles is part of the process of pursuing any goal. The virtue of fortitude, however, refers to specific obstacles. When describing this virtue, Joseph Pieper states: 'Fortitude presupposes vulnerability; without vulnerability there is no possibility of fortitude. [...] To be brave actually means to be able to suffer injury' (Pieper 1966, p. 117). Bravery helps a person to persevere in morally good opposition, even though opposition leads to the threat of painful consequences or to the actual experience of suffering. Breaking a relationship, exclusion from a group, and loneliness are sources of suffering. The person making such a decision is by no means unconscious of this danger.

In the analyses of Thomas Aquinas, there is one more important insight worth considering. He claims that fortitude is characterized by endurance or taking attack, but that endurance is more essential. To understand this position, it should be noted that a person takes attack when she/he is optimistic about succeeding (success, though difficult, is nevertheless 
possible), although s/he takes account of the risks involved, including that of failure. In the case of endurance, a person is in a more difficult situation. The forces s/he must face are more powerful than her/him, and s/he has little hope of success (Pieper 1966, pp. 126-133). The situation we are analysing here is, in a sense, a situation of endurance. The person or group whose aspirations the subject objects to is more powerful than the subject because that person or group will decide whether the relationship with the subject will be maintained or terminated. A subject can be excluded and rejected by the group or by a person close to her/him, and may therefore experience loneliness. After taking the decision to oppose another person, s/he conveys the initiative in making the decision as to whether to maintain or break the relationship to those who expected her/him to do something. Opposition to the individual's or group's activities means taking risks, and the consequence may be failure and the experience of separation from the people who matter. Opposition can lead to loneliness. Opposition combined with being prepared to accept loneliness is therefore conditional upon the virtue of fortitude, understood as endurance in such a difficult situation.

The question of fortitude leads our reflections to a specific virtue - that is, the virtue of longanimity. The translator of the Summa Theologiae into English explains that it is necessary to use this word on account of the comparison with magnanimity; but longanimity should be understood as conveying the notion of being long-suffering. Aquinas defines it as follows: 'Just as by magnanimity a man has a mind to tend to great things, so by longanimity a man has a mind to tend to something a long way off' (STh II-II, q. 136, a. 5). He also distinguishes this virtue from the virtue of patience. According to him, patience helps the subject to persevere in the pursuit of a difficult good, because this good is possible to achieve. It can be said that it is on the horizon and is approaching very slowly. In the case of longanimity, there is another situation. The good that the subject wants to acquire is distant; it does not come close; s/he cannot be sure that it is achievable. Opposition to the activities of the close person or group of persons and acceptance or rejection by them lead to loss of control over the situation. The subject cannot be sure that her/his situation will change in the future, since this would require persons close to her/him to understand the evil of their own actions, change their attitude, and rebuild their relationship with the person who expressed the objection. For this reason, I combine consent to loneliness with the virtue of longanimity.

In the Polish philosophy of education, built on the philosophy of Thomas Aquinas, the Latin term 'longanimitas,' is translated as dtugomyślność. It means taking into account a very distant future. Jacek Woroniecki maintains that the virtue of longanimity is the basic virtue of the educator. The educator attempts to support her/his pupil in development, but often never gets to see the positive outcomes of this work. According to Woroniecki, the educator cannot expect immediate results, because the pupil has free will and must make decisions about changing her/his way of acting. Sometimes it takes many years for the pupil to mature into making responsible decisions. Thanks to the virtue of longanimity, the educator does not succumb to sadness or discouragement in her/his work, although s/he does not see its effects directly (Woroniecki 2008, p. 242). Stanisław Gałkowski also indicates that the educator must be able to determine the temporal perspectives of her/his work and to prepare the pupil to face future challenges (Gałkowski 2016).

At first sight, readiness to accept loneliness as a consequence of choosing moral good has little to do with the virtue of temperance, the last of the cardinal virtues, which perfects the concupiscible power of the soul and relies on the ability to give up experiencing pleasure. However, philosophers who analyse the Thomistic theory of cardinal virtues point out that these virtues are present in each of the specific virtues (Szutta 2010, pp. 
81-92). This means that one should have the virtue of temperance in order to be ready for loneliness. The relationship between bravery, relying on readiness for loneliness, and the virtue of temperance becomes evident when we refer to a study of loneliness such as that of Piotr Domeracki, who in his introduction to monoseology ${ }^{1}$ draws attention to emotions that accompany interpersonal (especially close) relationships, and to feelings that result from breaking such relationships (Domeracki 2018, pp. 26-39). On the basis of this reflection, it can be concluded that interpersonal relationships are a source of pleasure, and the acceptance of loneliness is possible only when the individual is able to accept the absence of this pleasure.

The last of the virtues I want to refer to is hope. This is a virtue directed towards the difficult good in the future. As Thomas Aquinas says, 'when we were treating of the passion of hope, the object of hope is a future good, difficult but possible to obtain' (STh I-II, q.17, a. 1). What does it mean to hope? How do we differentiate hope from unreasonable optimism? Why should a person expect something specific to happen in the future? Witold Starnawski, in analysing the idea of hope in Aquinas, explains that hope reaches into the future, but is built on the past and present (Starnawski 2009, p. 115). For Thomas Aquinas, hope is a divine virtue, which means that it is based on trust in God's providence (Horowski 2012). Starnawski, however, refers to the natural foundations of hope, which include human nature and regularities associated with the maturation of a human being. In the case outlined here, the subject of the analyses is the situation in which one member of the group notices that the other members choose the morally evil goal of their aspirations, and therefore they are seeking not only to hurt another human being but also to act in a way that will negatively impact upon their personal and moral development. Making such a decision testifies to their immaturity. The person who notices this and objects, and thus decides to be rejected, does so in the hope that at least some of these 'immature' individuals will build a new relationship with her/him in the future, when they eventually perceive the defects of their reasoning and actions. S/he hopes that her/his opposition will cause close persons to raise doubts as to the rightness of the actions taken and in this way contribute to their own process of maturing. S/he bases her/his hopes on the stories of other people who have changed the way they behave under the influence of their experiences.

\section{Education as a Preparation for Making Difficult Moral Decisions. Conclusions}

The aim of the analyses undertaken in this article has been to answer the question: what character traits (moral virtues) should be shaped in maturing persons so that as adults they can resist moral evil, even when this will clearly lead to the experience of loneliness? To sum up this article, it should be stated that opposition to the morally evil activities of individuals or groups close to an acting subject, and readiness to experience the loneliness connected with this stance, are not at all easy. Loneliness is recognized as a source of suffering that we all try to avoid. For persons to be able to act in this way, they must have many positive character traits, referred to as virtues-primarily courage and other cardinal virtues

\footnotetext{
1 'The term 'monoseology' is derived from two combined ancient Greek words- 'monosé', which means 'loneliness', and 'logos' - translated as 'science'. Hence monoseology, in its wider meaning, is used to designate all sciences interested in analysing and conducting systematic research on loneliness; in a narrower sense the term 'monoseology' means simply just the philosophy of loneliness' (Domeracki 2015).
} 
(prudence, justice, moderation) - as well as virtues of hope and longanimity. Can education support the development of these virtues, and, if so, how? This is a big challenge for educational practice. The nature of these virtues is a testimony that preparation for making difficult decisions is not limited to supporting the development of intellectual competence. Working on the feelings of a maturing person is equally important. What are the conclusions from the above analyses for educational practice?

1. Although education cannot be reduced to intellectual development, it cannot undervalue intellectual development at the same time. As Maritain emphasizes, education is always an appeal to the intellect, because human nature is intellectual. The above analysis shows that the task of education is to prepare maturing people for a deeper understanding of reality, so that they recognize the effects of individual actions-the effects experienced by themselves, by strangers and by their loved ones. In the context of the situation analysed in this article, it is particularly significant for maturing individuals to be able to indicate how morally bad activities destroy the acting subjects themselves and influence their moral development. By referring to the ability to indicate the different direct and indirect effects of given actions, maturing people can understand how-by supporting their family members or friends in achieving bad goals or by opposing their aspirations- they contribute to the moral development of those close to them. Lack of such skills makes finding prudent solutions to moral dilemmas very difficult. Thus, the above analysis leads to the conclusion that an appropriate amount of time should be devoted in education to reflection on human nature, the person's morality, moral development and complicated moral dilemmas. As part of this reflection, the ability to find good solutions should be practised, even if these solutions are difficult ones requiring sacrifices. The above-mentioned Maritain called for such humanistic education. According to him, this consists in reading books, which reveal human nature, a person's moral development and the nature of interpersonal relationships (1943, p. 16).

2. If education is to support the development of moral virtues that facilitate the making of difficult decisions, then its primary goal is to support the development of the virtue of justice. The essence of justice is not the ability to solve matters fairly, but to strive for the good of all people who experience the effects of individual solutions. A person can be recognized as just if s/he strives for the good of all people-both her/his own good and the good of relatives and strangers. Thus, education for justice consists in shaping maturing people's responsibility for other people, regardless of whether they are family members of the acting subject, her/his friends or strangers. The school creates a space for education to be responsible for a stranger, because students meet strangers at school and must work with them. Teachers are those people who in adolescents can either reinforce individualistic and egoistic attitudes or support the development of altruistic attitudes and responsibility towards others who need help, even if they do not belong to the circle of close friends.

3. One of the most challenging aspects for education in making difficult moral decisions is to support the development of feelings. In the case analysed above, a fear of a painful experience - of suffering loneliness - is the feeling that should be addressed by education, that is, controlled by intellect and will. This fear of loneliness can be weakened through education for solitude. The goal of such education is primarily to tame the situation of being alone by discovering its positive aspects. Education for solitude is not about encouraging the breakdown of relationships and self-exclusion from the group. Rather, its purpose is to show and criticize stereotypes about aloneness, as well as to acquire the ability of those educated to accept it, if it occurs, so that students do not try to avoid it at all costsfor example, at the price of morally wrong choices. Contemporary culture and the technical context of living enable people to maintain a lot of contact with others and in consequence 
make it difficult to get used to being alone. At the same time, many educational institutions are creating silence zones (for example) where people can experience solitude and discover its positive dimensions.

4. The virtue of bravery is a key virtue in education that deals with tackling difficult moral challenges. This virtue can be presented in education in various forms. It can be combined with difficult activities that require sacrifices and that are associated with the risk of losing important goods. People who undertake difficult challenges for the benefit of other people are admired, that is, in interpersonal relationships the risk they take is compensated/rewarded. The situation analysed in this article is a completely different one, because the bravery of accepting the suffering of loneliness is not admired and rewarded in social relations. The person who makes difficult decisions that are unacceptable to her/his relatives suffers alone. Is it possible for education to support the development of the virtue of bravery understood as perseverance in loneliness? Certainly, teachers can draw students' attention to two types of bravery - the first accepted and rewarded and the second undertaken in aloneness and without the acceptance of loved ones. In addition, it is possible to provide students with examples of such activities that, despite positive moral value, are undervalued by those closest to the acting subject. It is possible to find such examples both in books read at school and in student relationships at school.

5. It is also worth noting that in answering the question of how human nature can acquire the perfection of virtue, Thomas Aquinas points to the importance of regular practice (Keenan 2016, 195). Developing this idea, Jacek Woroniecki states that no one can accomplish heroic deeds if s/he does not decide to sacrifice her-/himself for smaller or greater sacrifices for another human being in her/his daily life (Woroniecki 2008, 212). Why are exercises in moral virtues so important for their development? Woroniecki does not understand moral efficiency obtained through practice as the development of automatic habits. He distinguishes moral efficiency from habits. In his view, virtues as moral efficiency develop only when the individual deliberately takes action and experiences the effects of this action. If students understand the courage of undertaking morally good actions that are not accepted by their peers or friends, and they are able to find morally good solutions to dilemmas in school life, the teacher may encourage students to undertake morally good actions, despite the fact that their classmates exert pressure on them to choose a different solution in a given situation. The experience of the satisfaction of morally good actions, even if they lead to the breaking of significant relationships, can be a source of strength for them in the opposition that will be required when solving more serious moral dilemmas in adulthood.

6. The next challenge for education is to prepare maturing people for activities when the results of those activities will not be achieved in the near future, that is, to support the development of the virtue of longanimity. The development of this virtue is conditioned by the age of the students. It is worth noting, however, that it is possible to find among adults both those who expect immediate results for their own actions and those who strive for good without the certainty that it will ever be achieved. The virtue of longanimity does not therefore appear naturally. Its development must be supported. An example of people with the virtue of longanimity might be parents who try to convey to the child the values that are important to them even though the child rejects these values. They do not stop striving, believing that the child will someday - perhaps only after their death-understand the meaning of given values and refer to these values in her/his own life. Supporting the development of the virtue of longanimity is difficult, but the understanding of this virtue by adolescents would certainly be desirable, as would a little experience of the pursuit of good that may never be achieved. 
7. In this context, it is worth paying attention to the connection of the virtue of longanimity to the virtue of hope and to the importance of building hope. The virtue of hope differs from the character trait of optimism. The virtue of hope is based on rational premises and refers to the understanding of the nature of the reality in which the maturing person lives and acts. It is also a task for education to explain to students the difference between hope and optimism and thus support the development of the reason-based virtue of hope. The virtues of longanimity and hope can facilitate the maturing person in accepting loneliness, allowing the maturing person to believe that those s/he opposed will change in the future and will understand the evil of their own decisions. Such a hope allows the person to believe in rebuilding meaningful relationships.

8. The last of the virtues discussed in this article is the virtue of moderation, which consists in giving up the pursuit of pleasure when this resignation is a condition of achieving greater good. Supporting the development of the virtue of moderation is particularly difficult in a culture of consumption that is based on habituating maturing people to enjoying as much pleasure as possible. After all, interpersonal relationships are also a source of a kind of pleasure. In this context, the task of education is to help adolescents learn to distinguish between selfish pleasure and pleasure derived from the choice of a rational good that requires sacrifice. Furthermore, it involves enabling adolescents to learn to give up the pleasure of being with a person they like in favour of acting for the good of that person, even if it involves limiting the pleasure of being with her/him.

The catalogue of virtues needed for making difficult decisions resulting in loneliness could be much longer. One could, for example, refer to the virtues of responsibility or magnanimity. The choice of these six virtues was limited, however, by two aspects: firstly, by the scope of the article; and secondly, by the desire to refer to loneliness as a difficult and painful means to achieving the good of encouraging the maturation of close relatives or allies. In my opinion, identifying moral virtues that make it easier to decide on opposition and to accept the consequent rejection and loneliness sets orientation points for education. It is also the first stage in reflection on how to prepare maturing persons for opposition associated with the risk of the breakdown of relationships or rejection by people important to them and the loneliness that can result from these.

Open Access This article is licensed under a Creative Commons Attribution 4.0 International License, which permits use, sharing, adaptation, distribution and reproduction in any medium or format, as long as you give appropriate credit to the original author(s) and the source, provide a link to the Creative Commons licence, and indicate if changes were made. The images or other third party material in this article are included in the article's Creative Commons licence, unless indicated otherwise in a credit line to the material. If material is not included in the article's Creative Commons licence and your intended use is not permitted by statutory regulation or exceeds the permitted use, you will need to obtain permission directly from the copyright holder. To view a copy of this licence, visit http://creativecommons.org/licenses/by/4.0/.

\section{References}

Anscombe, G.E.M. 1958. Modern moral philosophy. Philosophy 33 (142): 1-19. https://doi.org/10.1017/ S0031819100037943.

Archer, M.S. 2000. Being Human. The Problem of Agency. Cambridge: Cambridge University Press.

Arendt, H. 1978. The Life of the Mind. San Diego: Harvest.

Arthur, J., K. Kristjánsson, T. Harrison, W. Sanderse, and D. Wright. 2016. Teaching Character and Virtue in Schools. London: Routledge.

Bauerschmidt, F. Ch. 2015. Thomas Aquinas. Faith, Reason, and Following Christ. Oxford University Press. 
Budzanowska-Weglenda, D., and M. Jewdokimow. 2019. Modern ascetic practices-Theory and practice from the perspective of catholic context. Paedagogia Christiana 44: 195-213. https://doi.org/10.12775 /PCh.2019.049.

Carr, D. 1991. Educating the Virtues. An Essay on the Philosophical Psychology of Moral Development and Education. London: Routledge.

Carr, D. 1996. After Kohlberg: Some implications of an ethics of virtue for the theory and practice of moral education. Studies in Philosophy and Education 15: 353-370. https://doi.org/10.1007/BF00368492.

Carr, D. 2017. Educating for the Wisdom of Virtue. In Varieties of Virtue Ethics, ed. D. Carr, et al., 319335. https://doi.org/10.1057/978-1-137-59177-7_19.

Cleveland, R. 2020. Aware I Am Alone: Intersections of Solitude and Mindfulness. Paedagogia Christiana 45: 37-52. DOI: http://dx.doi.org/10.12775/PCh.2020.003.

Curren, R. 2015. Virtue Ethics and Moral Education. In The Routledge Companion to Virtue Ethics, ed. L. Besser-Jones and M. Slote, 459-470. Abingdon: Routledge.

Dillon, R.S. 2001. Self-Forgiveness and Self-Respect. Ethics 112: 53-83.

Domeracki, P. 2015. Paradygmatyczne konceptualizacje samotności i wspólnotowości w dyskursie monoseologicznym [The Paradigmatic Conceptualizations of Loneliness and Communitivenessin a Monoseological Discourse]. Filozofia Chrześcijańska 12: 33-56.

Domeracki, P. 2018. Horyzonty i perspektywy monoseologii. Filozoficzne studium samotności [Horizons and Perspectives of Monoseology. A Philosophical Study of Loneliness]. Toruń: Wydawnictwo Naukowe Uniwersytetu Mikołaja Kopernika.

Domeracki, P. 2020. Three rival versions of a correlation between solitude and communitiveness in a monoseological discourse. Paedagogia Christiana 45: 23-36. https://doi.org/10.12775/ PCh.2020.002.

Eaude, T. 2016. New Perspectives on Young Children's Moral Education: Developing Character through a Virtue Ethics Approach. London: Bloomsbury Academic.

Gałkowski, S. 2016. Dtugomyślność. Wprowadzenie do filozofii wychowania [Longanimity. An introduction to the philosophy of education]. Kraków: Akademia Ignatianum, Wydawictwo WAM.

Gilson, E. 2002. Thomism. The Philosophy of Thomas Aquinas, trans. L. K. Shookand, A. Maurer. Toronto: Pontifical Institute of Mediaeval Studies.

Henry, J. 1980. Loneliness and Vulnerability. In The Anatomy of Loneliness, ed. J. Hartog, J.R. Audy, and Y.A. Cohen, 95-110. New York: International Universities Press.

Horowski, J. 2009. Podmiotowość w pedagogice chrześcijańskiej o inspiracji tomistycznej [Being a Subject in the Light of the Christian Educational Theory Based on Thomistic Philosophy]. Paedagogia Christiana 24: 63-78. https://dx.doi.org/10.12775/PCh.2009.029.

Horowski, J. 2012. Nadzieja jako sprawność woli O. budzeniu i wychowaniu nadziei [Hope as a Habit of the Will. About Awaking and Upbringing of the Hope]. Roczniki Pedagogiczne 4 (40): 21-36.

Horowski, J. 2014. The category of competence and the theory of moral education in the light of the philosophy of Jürgen Habermas and Jacques Maritain. Edukacja Dorostych 1: 59-73.

Horowski, J. 2015. Wychowanie moralne wedtug pedagogiki neotomistycznej [Moral Education According to neo-Thomistic Pedagogy]. Toruń: Wydawnictwo Naukowe UMK.

Kaźmierczak, P. 2019. Neoarystotelesowska filozofia edukacji w ujęciu Alasdaira MacIntyre'a [The NeoAristotelian Philosophy of Education in the Legacy of Alasdair MacIntyre]. Kraków: Wydawnictwo Naukowe Akademii Ignatianum.

Keenan, J.F. 2016. Virtues. In The Cambridge Companion to the Summa Theologiae, ed. P. McCosker and D. Turner, 194-205. Cambridge: Cambridge University Press.

Kostyło, P. 2015. Ferdinand Ebner i paradoks samotności [Ferdinand Ebner and the Paradox of Solitude]. Paedagogia Christiana 35: 79-97. https://doi.org/10.12775/PCh.2015.004.

Kristjánsson, K. 2015. Aristotelian character education. London: Routledge.

MacIntyre, A. 2007. After Virtue. A study in moral theory. Notre Dame: University of Notre Dame Press.

Martini, C. M. 1992. Perseverance in Trials: Reflections on Job. Trans. M. J. O’Connell. Collegeville, Minnesota: The Liturgical Press.

Maritain, J. 1943. Education at the Crossroads. New Heaven and London: Yale University Press.

Maritain, J. 1967. The Education of Man, ed. D. Gallagher and I. Gallagher. Noter Dame: University of Notre Dame Press.

Maritain, J. 1990. An Introduction to the Basic Problems of Moral Philosophy. New York: Magi.

Mausbach, J. 1920. Grundlage und Ausbildung des Charakters nach dem hl. Thomas von Aquin. Freiburg im Breisgau: Herder.

McGregor, P.J. 2016. Heart to Heart: The Spiritual Christology of Joseph Ratzinger. Eugene, Oregon: Pickwick Publications.

Merton, T. 1998. The Seven Storey Mountain. Bardstown, Kentucky: Harcourt Brace Jovanovich. 
Mijuskovic, B.L. 2015. Feeling Lonesome. The Philosophy and Psychology of Loneliness. Santa Barbara, Denver: Praeger.

Pieper, J. 1966. The Four Cardinal Virtues: Prudence, Justice, Fortitude, Temperance. Chicago: University of Notre Dame Press.

Rajský, A. 2018. What's wrong in modern education? Maritain's warning is valid today more than ever. Caritas et Veritas 8: 59-77.

Rembierz, M. 2013. Oblicza samotności w edukacji. Samotność i odosobnienie wśród zasad wychowania intelektualnego i kształcenia samodzielności poznawczej [Lonliness in Education. Lonliness and Isolation among the Rules of Intellectual Upbringing and Shaping Cognitive Independence]. Horyzonty Wychowania 23: 55-75.

Richardson, H. S. 2018. Moral Reasoning. In The Stanford Encyclopedia of Philosophy (Fall 2018 Edition), ed. E. N. Zalta. https://plato.stanford.edu/archives/fall2018/entries/reasoning-moral/ [Access: 10.02.2020].

Snow, N.E. 2016. How habits make us virtuous. In Developing the Virtues. Integrating Perspectives, ed. J. Annas, D. Narvaez, and N.E. Snow, 135-156. Oxford: Oxford University Press.

Spaemann, R. 2006. Persons: The Difference between "Someone” and "Something”. Trans. O. O'Donovan. Oxford: Oxford University Press.

Starnawski, W. 2009. Matka głupich? Filozoficzne aspekty nadziei [Mother of the Foolish? Philosophical Aspects of Hope]. Paedagogia Christiana 24: 113-123. https://doi.org/10.12775/PCh.2009.032.

Stern, J. 2014. Loneliness and Solitude in Education: How to Value Individuality and Create an Enstatic School. Oxford: Peter Lang.

Stern, J., and M. Wałejko. 2020. Solitude and Self-Realisation in Education. Journal of Philosophy of Education 54 (1): 107-123.

Szutta, N. 2010. Jedność cnót jako warunek normatywności cnoty. W obronie doktryny jedności cnót [The Unity of Virtue as a Condition of Virtue's Normativity: Defending the Doctrine of the Unity of Virtue]. Ethos 92: 78-93.

Szutta, N. 2017. Czy istnieje coś, co zwiemy moralnym charakterem i cnota? Dyskusja z sytuacjonistyczna krytyka etyki cnót [Is There Anything Like Moral Character or Virtue? A Debate with the Situationist Criticism of Virtue Ethics]. Lublin: Academicon.

Thomas Aquinas. 1485[1947]. Summa Theologica [STh]. https://www.ccel.org/ccel/aquinas/summa.html [Access: 15.02.2019].

Tillich, P. 1980. Loneliness and Solitude. In The Anatomy of Loneliness, ed. J. Hartog, J.R. Audy, and Y.A. Cohen, 547-553. New York: International Universities Press.

Wałejko, M. 2007. Samotność a osamotnienie-Osobowe stany egzystencjalne człowieka. Analiza etycznometafizyczna [Loneliness and Solitude-The Personal Existential States. An Ethical and Metaphysical Analysis]. Roczniki Nauk Społecznych 2: 45-66.

Wałejko, M. 2016. Osobno i razem. Personalistyczne wychowanie do samotności i wspólnoty [Separately and together. Personalistic education towards solitude and communitivity]. Szczecin: Uniwersytet Szczeciński.

Wojtyła, K. 1994. Osoba i czyn oraz inne studia antropologiczne. Lublin: Towarzystwo Naukowe KUL.

Woroniecki, J. 1922. Metoda i program nauczania teologii moralnej. Lublin: Uniwersytet Lubelski.

Woroniecki, J. 2008. W szkole wychowania. Teksty wybrane. Lublin: IEN.

Żywczok, A. 2019. Prawość i cnoty pokrewne. Reaktywacja cnót istotnych w procesie wychowania moralnego [Rectitude and the Related Virtues. Revival of Essential Virtues in the Process of Moral Education]. Forum Pedagogiczne 9(2). https://doi.org/10.21697/fp.2019.2.29.

Publisher's Note Springer Nature remains neutral with regard to jurisdictional claims in published maps and institutional affiliations. 